1:500000 reconnaissance mapping in the Precambrian of the Sukkertoppen region, southern West Greenland. Rapp. Grønlands geol. Unders. 90, 50-54.

Berthelsen, A. 1960: Structural studies in the pre-Cambrian of western Greenland II. Geology of Tovqussap nunâ. Bull. Grønlands geol. Unders. 25 (also Meddr Grønland 123,1), 223 pp.

Berthelsen, A. 1962: Structural studies in the pre-Cambrian of western Greenland III. Southern Sukkertoppen district. Bull. Grønlands geol. Unders. 31 (also Meddr Grønland 123,2) 46 pp.

Black, L. P., Moorbath, S, Pankhurst, R. J. \& Windley, B. F. 1973: ${ }^{207} \mathrm{~Pb} /{ }^{206} \mathrm{~Pb}$ whole rock age of the Archaean granulite facies metamorphic event in West Greenland. Nature Phys. Sci. 244, 50-53.

Bridgwater, D., Keto, L., McGregor, V. R. \& Myers, J. S. 1976: Archaean gneiss complex of Greenland, In Escher, A. \& Watt, W. S. (edit) Geology of Greenland, 18-75. Copenhagen: Geol. Surv. Greenland.

Lauerma, R. 1964: On the structure and petrography of the Ipernat dome, western Greenland. Bull. Grønlands geol. Unders. 46 (also Bull. Comm. géol. Finlande 251), 88 pp.

V. R. M. Atangmik, 3912 Sukkertoppen, Greenland.

\title{
Field work in the Ujaragssuit nunât area, Ivisârtoq region, inner Godthåbsfjord, southern West Greenland
}

\section{Brian Chadwick and Martin A. Crewe}

Following the successful completion of the Buksefjorden project, 63 V.1 N (1972-1979), the Geological Survey of Greenland and the Department of Geology, University of Exeter, have begun another joint project in the Ivisârtoq region, $64 \mathrm{~V} .2 \mathrm{~N}$, in inner Godthåbsfjord. The field programmes (1981-1984) and laboratory studies at Exeter are being organised on lines similar to those of the Buksefjorden project, with supervision of four research assistants by B. Chadwick and K. Coe. M. A. Crewe and S. Robertson began work as research assistants in 1981. The generous support by the Survey, the University of Exeter, and the Natural Environment Research Council, UK, is gratefully acknowledged.

During the 1981 field season Chadwick and Crewe worked in Ujaragssuit nunat in the north-east and Coe and Robertson worked in the Kangiussap nunâ area in the west of the Ivisârtoq region. Because of radical differences in the geology of each area, marked especially by the degree of development of Nûk gneisses, the field reports are given as two separate accounts, although they are complementary. The Ivisârtoq region was mapped on a rapid reconnaissance basis in 1976 (Allaart et al., 1977), and results of more detailed studies in certain parts of the region have been presented by Walton (1976), Friend \& Hall (1977), Hall \& Friend (1979) and Hall (1980). 
Most of the rock types mapped in Ujaragssuit nunât in 1981 have their counterparts in the type area of the Akilia association, Amîtsoq gneisses, Ameralik dykes, Malene supracrustal rocks and Nûk gneisses in north-west Buksefjorden and the Godthåb district (McGregor, 1973; Bridgwater et al., 1976; Chadwick \& Nutman, 1979). Age relations are also similar and so correlations are made here with no further discussion.

\section{Akilia association}

The Akilia association is represented as enclaves and heavily migmatised sheets in the Amîtsoq gneisses. Some of the enclaves, in particular the ultramafic rocks, are up to $100 \times 400 \mathrm{~m}$ in size. The ultramafic enclaves commonly occur as trains mappable for up to 1 $\mathrm{km}$. The sheets of migmatised Akilia rocks comprise amphibolites and metasedimentary rocks together up to $300 \mathrm{~m}$ wide and $3 \mathrm{~km}$ in length. These sheets make valuable structural markers in the homogeneous foliated Amitsoq gneisses. The most abundant Akilia lithology is amphibolite, ranging from homogeneous to banded, garnetiferous, diopsidic or leucocratic. Also abundant, and generally the most obvious, are the ultramafic rocks. Dunitic rocks are especially common, forming large mappable enclaves weathering to a pink-sandy yellow which contrasts strongly with the grey gneisses. These olivine-rich rocks contain variable proportions of phlogopite, green amphibole (including actinolite which is locally a brilliant chrome green), brown amphibole and chlorite. Tremolite replaces olivine and commonly occurs as veins cutting across the planar fabric in many of the enclaves. The ultramafic rocks have been strongly disrupted by sheets of Amitsoq foliated gneiss or coarse white foliated pegmatites. Reaction with the acid rocks has given rise to coarse bladed tremolite and actinolite, biotite and blue soapstone. Layers of chromite up to $2 \mathrm{~m}$ thick and an associated primary igneous texture of olivine and chromite resembling 'negative leopard spot ore' (Radhakrishna, 1957) were found in one locality of Akilia metadunite. Other Akilia lithologies include heavily migmatised garnet-biotite-feldspar-quartz gneisses (presumably paragneiss) and the quartz-magnetite and thinly laminated, cherty silicate facies iron formations seen in north-west Buksefjorden. A solitary enclave of white quartzite containing green mica (?fuchsite) was found in the north-west. Grey marble with a fine-scale layering suggesting original bedding was found in association with diopsidite in the north-east of the area. The occurrence of Akilia ultramafic rocks within the sheets of Akilia amphibolites and metasedimentary rocks suggests the original ultramafic rocks were intruded probably as sills, into the supracrustal host rocks.

\section{Amitsoq gneisses}

The Amîtsoq gneisses, recognised by the presence of Akilia enclaves and Ameralik dykes, are entirely of the thinly foliated, pegmatite-banded multiphase variety (Chadwick \& Nutman, 1979). No homogeneous augen granite varieties of Amitsoq gneiss were seen, except for a few thin sheets in the multiphase gneisses in the north-east.

Some Amitsoq gneisses have been strongly affected by feldspar blastesis and appear to have been transformed to new gneisses. The transformed gneisses take on a nebulitic-schlieric aspect and Ameralik dykes degenerate to hornblende wisps. The appearance of these gneisses is much like that described from Tinissâq in south-east Buksefjorden (Chadwick et al., 1974; Wells, 1976). 
The Amîtsoq gneisses have also undergone transformation to coarse pink pegmatite and pink granite in the north-east of the area close to the edge of the Inland Ice. Many of the pegmatites are discordant to the gneiss foliation, but new feldspar and biotite in the pegmatites has nucleated on pre-existing minerals in the host gneiss. Many of the pegmatites are banded. The pink granitic material is of limited occurrence, but its replacement origin is indicated by the nebulitic-schlieric survival of traces of the original Amitsoq gneiss foliation. Allanite is abundant in the pegmatites and granite. The area of pink pegmatites extends approximately north-west from the edge of the Inland Ice. It appears to be independent of the structure and is of a late origin such that it may be part of the events related to the formation of the Qôrqut granite.

\section{Ameralik dykes}

Ameralik dykes are abundant in the Amitsoq gneisses. Of the categories recognised in north-west Buksefjorden (Chadwick, 1981), A, B and C Ameralik dykes are the most common in the Ujaragssuit nunât area. D Ameralik dykes are rare, a factor that may be significant in the interpretation of Malene-Amitsoq relations as a cover-basement association in north-west Buksefjorden where D Ameralik dykes are common. Intersections between Ameralik dykes in Ujaragssuit nunât are rare. In most of the area the Ameralik dykes are thin, generally no more than $2 \mathrm{~m}$ thick, but in the north-east dykes up to $20 \mathrm{~m}$ thick are common. Some are dark homogeneous amphibolites with a marked doleritic aspect. Other thick dykes contain feldspars of B and C Ameralik dyke type. These large dykes may be the equivalents of the large discordant dykes at Isukasia. Their relation to the main Ameralik dyke types has not been seen, but they appear to have had a similar tectonic history. Most Ameralik dykes are intensely deformed, boudiné or isoclinally folded.

\section{Malene supracrustal rocks}

The Malene rocks are restricted to a thin, 200-700 m sheet folded around a large closure dominating the structure of Ujaragssuit nunât (fig. 20). The Malene rocks mapped occur on the eastern limit of this structure and in a V-shaped synformal structure in the south-east. The Malene rocks comprise homogeneous and banded amphibolites like Malene homogencous amphibolites and Malene banded amphibolites in north-west Buksefjorden (Chadwick, 1981). Some parts of the banded amphibolites resemble the intensely deformed pillow lavas of Ivisârtoq, but definite pillows were not identified unambiguously in Ujaragssuit nunât. These homogeneous and banded formations are locally garnetiferous. Malene garnetiferous amphibolite types (Chadwick, 1981) with anthophyllite-rimmed garnets were not seen. The homogeneous amphibolites are locally metagabbroic. The homogeneous amphibolites contain layers of garnet-biotite-quartz rock up to $1 \mathrm{~m}$ thick resembling Qilángârssuit Malene Gneiss on the islands in north-west Buksefjorden (Beech \& Chadwick, 1980). These paragneisses are much more restricted in their occurrence compared with the amphibolites. No cordierite-quartz rocks of Simiútat Malene Gneiss type were seen. One other possible metasedimentary rock comprises rusty weathering quartz-mica-gedrite (?) schist with a sulphurous odour. This rock commonly occurs adjacent to Malene ultramafic sheets. Ultramafic rocks are common in the belt of Malene rocks. They range from massive olivine-pargasite(?)-chlorite rocks with tremolite prisms to tremolite-actinolite schists, 


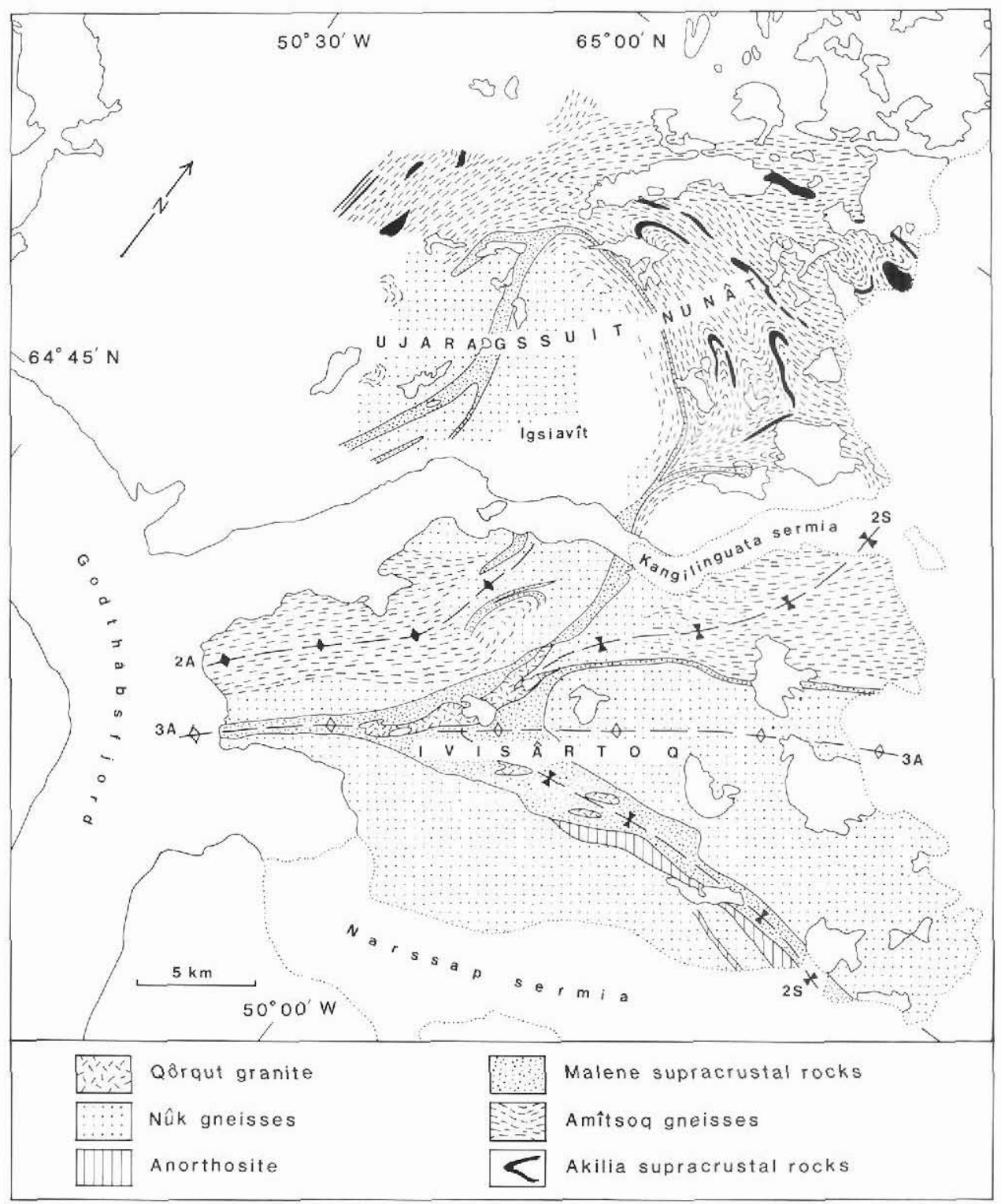

Fig. 20. Geological map of Ujaragssuit nunât mapped in 1981 and Ivisàrtoq mapped by Friend \& Hall (1977). Fold axial traces in the Ivisârtoq area are from Hall \& Friend (1979, fig. 1). 
talc-tremolite schists and blue-grey soapstone. Some of the actinolite is brilliant chrome green like that in the Akilia ultramafic rocks. The ultramafic rocks, including the massive varieties, have marked $S$ fabrics of tectonic origin. Tremolite prisms locally form garben grown across the $S$ fabric.

Lithologies resembling A and D Malene dykes of north-west Buksefjorden (Chadwick, 1981) were seen in a few instances, but no unambiguous discordances were seen. Of particular interest is the rare occurrence of thin amphibolites with plagioclase aggregates. One of these sheets, $15-20 \mathrm{~cm}$ thick, occurs in garnet paragneiss. Another sheet with plagioclase aggregates occurs with a barely discernible discordance to the $S$ fabric in a hornblende-rich amphibolite which is part of a differentiated metagabbroic complex. The sheet is $60 \mathrm{~cm}$ thick and is cut by pegmatites like its host amphibolite. White rims are visible around some of the creamy feldspar knots, but it is not clear whether the feldspar knots are anorthositic like the typical C Ameralik dykes (Chadwick, 1981). The sheet has thin pale margins. These thin sheets with white feldspar aggregates have aspects in common with B and C Ameralik dykes. The thin sheets are interpreted as dykes or sills. Some of the thick homogeneous amphibolites also contain feldspar aggregates considered to have been of igneous origin. Concordant sheets of homogeneous amphibolite up to $1 \mathrm{~m}$ thick are relatively common in the banded amphibolites. Similar sheets with low-angle discordance in deformed pillow lavas noted during a reconnaissance of Malene rocks at Ivisârtoq suggest that the concordant sheets in the Malene rocks of Ujaragssuit nunât may also have been dykes that were rotated into parallelism with banding during deformation.

\section{Contact relations}

Amîtsoq multiphase gneisses occur east and west of the Malene rocks on the eastern limit of the central Ujaragssuit nunât structure (fig. 20). These gneisses also form the core of the $\mathrm{V}$ synform. Contact relations with the Malene belt are ambiguous. The gneisses in many places on the east of the eastern limb have sharp contacts with Malene amphibolites and ultramafic rocks. White pegmatites are common along the contact, some being discordant. In some instances a thin zone of biotite schist with quartz nodules occurs between the gneiss and the supracrustal rocks. It is conceivable that this schist is a recrystallised mylonite, but otherwise there is no other suggestion of a thrust. An igneous intrusive contact is equally possible on the basis of the field evidence. The western contact of the thin belt is also ambiguous, although the presence of local homogeneous Nûk gneiss along parts of the contact suggests an intrusive relation. Large, irregular and concordant masses of white, biotite pegmatites are abundant within the supracrustal belt and in the extreme south-east in the area of the pinched V synform closure in the Malene rocks (fig. 20).

From the intrusive relation of Nûk gneisses on the western contact, it can be concluded that the Malene rocks were in contact with Amitsoq gneisses to the east and west before the Nûk injection. Therefore the Malene contacts with Amîtsoq gneisses are either intrusive, tectonic or unconformities. If the last, then the Malene belt must form the core of a nappe. Assuming the Amitsoq gneisses are older than the Malene rocks, then at least one contact (probably both) must be tectonic, namely a thrust of many kilometres displacement. The thrusting took place before the formation of the regional isoclinal folds described later. Most of the Malene rocks carry strong $L S$ fabrics older than and contemporaneous with the regional isoclines. 


\section{Nûk gneisses}

The Nûk gneisses outcrop mainly within and to the west of the thin arcuate belt of Malene rocks. There are two main types of gneiss although the field relationships between the two remain to be established. Pegmatite-banded, quartzo-feldspathic gneisses are more common near the Malene supracrustal belt whereas nebulitic, more finely-foliated types are usually found in the central area around Igsiavit (fig. 20). The gneisses are tonalitic-granodioritic with hornblende or biotite as the dominant mafic material. Both types of gneiss have a quartz-feldspar mineral lineation developed locally, but this is often indistinct in the more nebulitic gneisses. Minor folds are coaxial with the mineral lineation but are very uncommon except in the vicinity of the supracrustal belt. The banded gneisses occur in sheets slightly discordant to foliation and deformed Ameralik dykes in the Amîtsoq gneisses and in some instances to foliation in the Malene amphibolites. Enclaves of both Amitsoq gneisses and Malene supracrustal rocks are preserved in the main outcrops of Nûk gneisses.

\section{Structure}

The sheet of Malene rocks defines an open synformal closure plunging south in the north-west and a tight cusp-like synform with steep north-east plunge in the south-east (fig. 20). Fold axial traces of steep regional isoclines in Amitsoq gneisses and Akilia rocks swing around the Malene sheet in the east and appear to be contemporaneous with the synformal cusp (fig. 20). These fold axial traces also swing around the north and west of the open synformal closure of Malene rocks, but they diverge when traced to the north-east (fig. 20).

This pattern supports the interpretation of the regional structure of Ivisârtoq by Hall \& Friend (1979). In Ujaragssuit nunât they show that the open synformal closure of the Malene rocks forms part of an early isocline of their $F_{2}$ generation which is refolded by a synform $\left(F_{3}\right)$ trending north-east across Ujaragssuit nunât. The regional isoclines and the synformal cusp in Ujaragssuit nunât (fig. 20) could be correlated with $F_{2}$. Such a relation is supported by the common style of deformation, coaxial $L$ fabrics and the occurrence of thin foliated pegmatites along fold axial surfaces.

However, while the regional structures in Ujaragssuit nunât appear to support the hypothesis of Hall \& Friend (1979), a problem arises in the interpretation of the synformal cusp and the synform labelled $2 S$ immediately south-east of Kangilínguata sermia (Hall \& Friend, 1979, fig. 1) because there appears to be no intervening antiform (fig. 20). An alternative explanation of the structure of Ujaragssuit nunât is that it is part of a regional dome and basin system, a view based on changes in trend of foliation in Amitsoq gneisses north of Ujaragssuit nunât and $65^{\circ} 00^{\prime} \mathrm{N}$ (fig. 20). The open synformal closure of the Malene sheet in Ujaragssuit nunât may form the northern end of a very large dome and the tight synform in the south-east may be part of a complementary basinal cusp. This hypothesis will be tested further in later periods of field mapping.

\section{References}

Allaart, J. H., Jensen, S. B., McGregor, V. R. \& Walton, B. J. 1977: Reconnaissance mapping for the 1:500000 map sheet in the Godthåb-Isua region, southern West Greenland. Rapp. Grønlands geol. Unders. 85, 50-54. 
Beech, E. M. \& Chadwick, B. 1980: The Malene supracrustal gneisses of northwest Buksefjorden: their origin and significance in the Archaean crustal evolution of southern West Greenland. Precambrian Res. 11, 329-355.

Bridgwater, D., Keto, L., McGregor, V. R. \& Myers, J. S. 1976: Archaean gneiss complex of Greenland. In Escher, A. \& Watt, W. S. (edit.), Geology of Greenland, 18-75. Copenhagen: Geol. Surv. Greenland.

Chadwick, B. 1981: Field relations, petrography and geochemistry of Archaean amphibolite dykes and Malene supracrustal amphibolites, northwest Buksefjorden, southern West Greenland. Precambrian Res. 14, 221-259.

Chadwick, B. \& Nutman, A. P. 1979: Archaean structural evolution in the northwest of the Buksefjorden region. Precambrian Res. 9, 199-226.

Chadwick, B., Coe, K., Gibbs, A. D., Sharpe, M. R. \& Wells, P. R. A. 1974: Field evidence relating to the origin of 3000 m.y. gneisses in southern West Greenland. Nature Lond. 249, 136-137.

Friend, C. R. L. \& Hall, P. 1977: Field work in the Ivisârtoq area, inner Godthåbsfjord, southern West Greenland. Rapp. Grønlands geol. Unders. 85, 54-60.

Hall, P. 1980: The tholeiitic and komatiitic affinities of the Malene metavolcanic amphibolites from Ivisârtoq, southern West Greenland. Rapp. Grønlands. geol. Unders. 97, 20 pp.

Hall, P. \& Friend, C. R. L. 1979: Structural evolution of the Archaean rocks in Ivisârtoq and the neighbouring inner Godthåbsfjord region, southern West Greenland. Geology 7, 311-315.

McGregor, V. R. 1973: The early Precambrian gneisses of the Godthåb district, West Greenland. Phil. Trans. R. Soc. Lond. A 273, 343-358.

Radhakrishna, B. P. 1957: The mode of occurrence of chromite at Byrapur, Mysore State, India. Bull. Mysore Geol. Assoc. 12.

Walton, B. J. 1976: Mapping of Archaean rocks in the inner Godthåbsfjord region, southern West Greenland. Rapp. Grønlands geol. Unders. 80, 72-77.

Wells, P. R. A. 1976: The metamorphic petrology of high grade Archaean rocks, Buksefjorden, southern West Greenland. Ph. D. thesis, University of Exeter.

Department of Geology,

The University,

Exeter EX4 4QE

Devonshire,

U.K.

\section{Mapping of Archaean rocks in part of the Ivisârtoq sheet}

\section{Kenneth Coe and Steve Robertson}

Parts of Kangiussap nunâ were mapped in the 1981 field season at a scale of 1:20000 as the start of the Ivisârtoq project (Chadwick \& Crewe, this report). This area was surveyed on reconnaissance scale in 1975 and brief accounts were published (Walton, 1976; Allaart et al., 1977). These accounts proved to be of value in predicting the type of geology to be expected, but in the course of the mapping contradictions were revealed and some of the speculative views expressed were found to be unacceptable. Problems centre on establishing 